\title{
Fate of translocated wild-caught and captive-reared stone martens (Martes foina)
}

\author{
Jan Herr • Laurent Schley • Timothy J. Roper
}

Published online: 24 January 2008

(C) Springer-Verlag 2008

\section{Erratum to: Eur J Wildl Res}

DOI 10.1007/s10344-007-0158-3

The reference "Robertson and Harris (1995a)" was published with the wrong page numbers. The corrected reference is shown below:

Robertson CPJ, Harris S (1995a) The behaviour after release of captive-reared fox cubs. Anim Welfare 4:295-306

The online version of the original article can be found at http://dx.doi. org/10.1007/s10344-007-0158-3.

J. Herr · T. J. Roper

Department of Biology and Environmental Science,

University of Sussex,

Brighton, UK

J. Herr $(\bowtie)$

Musée National d'Histoire Naturelle,

Centre de Recherche Scientifique,

25 rue Münster,

2160 Luxembourg, Luxembourg

e-mail: janherr_lux@yahoo.com

L. Schley

Service de la Conservation de la Nature,

Direction des Eaux et Forêts,

Luxembourg, Luxembourg 